\title{
Direction and Effectiveness of Trade Policy Reform: A Case Study of Indo-Nepal Trade Development
}

\author{
Prof. R. K. Shah, PhD \\ Central Department of Rural Development, Tribhuvan University \\ Email for correspondence: drrk.nepal@gmail.com
}

\begin{abstract}
This paper intends to assess direction and effectiveness of trade policy of Nepal by studying Trade Development between India and Nepal. It follows the comparative method based on the correlation and the simple logarithmic regression model between two-policy implication period: Import Intensive Trade Policy and State led imports intensive Trade Policy (1985-1994) and Export Intensive Trade Policy under Liberalization Regime (1995-2009). This study is based on the secondary data of trade published by the government agency including Central Bureau of Statistics (CBS), Ministry of Finance (MoF), Trade Promotion Center, World Bank, Asian Development Bank.
\end{abstract}

Key words: Trade, trade policy shift, effectiveness, correlation coefficient and GDP.

\section{Introduction}

Trade is traditionally understood as exchange of goods. In the modern eras, trade refers to international trade. It is a character of open economy in accordance with Keynesian economy. Paul's (1999) comments are on it as the exchange of goods and services among different countries or trade across the political boundaries (Cherunilam, 2007). In general, its constituents are import and export trade. Origin of trade policy shift is controversial but it was started 5,000 years back as exchange of goods, so called barter system. Giving top priority on its cross boundary trade development at tax exemption privileges, Mercantilist had defined it as source of National wealth and prosperity in 17 th and 18 th period. The beginning of international trade can be said to the period. Industrial revolution in the 18th century had established classical doctrine of laissez faire in trade led by Adam Smith, Ricardo, etc. Invention and use of money diversified trade of raw materials and goods at international level. Consequently, world trade increased drastically and reached a peak of about 70 billion dollars in 1929 (Shakya, 1991, p. 19). In the post World War II, Keynesian doctrine came into existence. Development of science and technology had made infinite prospects of International trade. In 1947, GATT (General Agreement on Tariffs and Trade) was done in Geneva by more than 100 countries. It has been shifted into WTO. In simple, international trade is towards liberalism.

Analysis and observations are not universal. In the analysis of economic thoughts, the classical and neo-classical economists give importance to it in a country's development as an engine of growth. Adam Smith (1976) advocated lassie faire economy. He pointed out that free international trade increases division of labor and economic efficiency and consequently economic welfare. He considered international trade as productivity gain, absolute cost gain and vent for surplus gain. Ricardo (1817) has demonstrated that the basis of trade is the comparative cost difference. At present, trade liberalization is a latest form of the classical economist's lassie faire. Observations and statistics of world trade and its composition in terms of increasing share of developing countries are evident that for trade opportunity led benefit and productive, although G- 
8 countries control it. In addition further, Heckscher-Ohlin Theory points out that comparative cost difference is the basis of international trade (Cherunilam, 1997). However, benefit of foreign trade is a big issue of global inequality and poverty. Therefore, least developed countries (LDCs) haven't improved its share and development in the world trade, although some developing countries had done better. Therefore, pessimistic views can be found but reality is obliged for choosing globalization.

Another side of coin is optimistic view that role of foreign trade in LDCs is substantial in globalization context for economic development and higher economic growth. In regards to LDCs, Pant (2005) describes that foreign trade is crucial to developing and LDCs for a variety of reasons. Firstly, it is often the principal mechanism for achieving the benefits of globalization. Secondary, the continuing reallocation of manufacturing actions from industrial to developing and LDCs provides many opportunities for examined trade both in goods and services. Haberler (1959) opines that international trade has made a tremendous contribution to the development of less developed countries in the 19th and 20th centuries and can be expected to make an equally big contribution in the future and that substantial free trade with marginal, insubstantial corrections and deviations is the best policy from the point of view of economic development. In addition, international trade and economic growth have nexus. Pant (2005) has pointed that the link between trade, development and economic growth is symbiotic one. Despite existence of issues, role of International trade is inevitable sector instrument to LDC, like Nepal for future development prospective through divergent specialization opportunity and benefit in all productive sectors. It is possible when appropriate trade policy is switched on in LDC, Nepal.

\section{Historical Observation on Trade and Policy Shift}

Historical evidence describes explicitly that Indo-Nepal Trade has been preferred major trade on Nepal more than Tibet since Malla period. The political economy can be observed into four periods: Malla-Shah Dynasty, Rana Regime, Panchyat Regime and Democratic system for analyzing trade and policy shift. Up to the earlier period of Rana Regime, trade policy was expansionary and protective character. In other words, the policy was export trade intensive but restrictive to import trade. Trade pundits and political economists advocate that it was hidden reason behind prosperity of the country at that time period. In the mid period of Junga Bahadur Rana, trade policy was slightly towards import intensive, rather than restrictive import trade after visiting in Britain. Indo-Nepal trade that was approximately more than 70 percent was import dominance led higher rate growth of trade deficit. Once again it was adopted in the Panchyat period (1970-1980) for revenue prospective, although the government had given priority on Industrial development. Indo-Nepal was leading. Its negative consequence was macro economic instability and crisis. Since 1980, the country has shifted trade policy towards export intensive.

The policy was shifted towards liberalization for competition, interdependency and efficiency in 1980 s, in the course of globalization in the World. Its consequences are relatively vibrating trade pattern, composition and direction towards growth and diversification of export. Then, Indo-Nepal trade dominance declined with the growth of third world countries trade. However, Indo-Nepal trade share was still larger than third world countries trade. The trade statistics shows unsatisfactory in terms of its more negative fueling economic growth and economic development because of relatively lower exports trade growth. Its acceleration and strength can be found in 1990. It has brought vibration in international trade development. However, macro-economic indicators indicate unsatisfactory. Having on unsettled key economic 
issues led instabilities, it raises a question, is the adopted trade policy appropriate to this landlocked country's trade development?

\section{Trade Policy Shift (TPS) in Global Contexts}

Since nature of policy is dynamic, shifting policy is continuous process depending on variables of time, people government and external factor. Studies and observations show two major reasons behind policy dynamism such as National need and Donor driven. The government is obliged to develop the country. Its national need leads to policy shift. Simultaneously, it may be a pre-condition of donors with external influence.

During the last two decades, the policy advice of bilateral and multi-lateral donors to developing countries has been centered on favoring greater market openness and better integration into the global economy. Two major assumptions underpin this advice: (a) that outward-oriented economies appear to have performed better in terms of economic growth, and (b) that raising average incomes generally benefits all groups of people, including the poor (Coudouel, 2005). Therefore, Trade Policy Shift (TPS) in developing country like Nepal has been normal phenomenon under the influence and recommendation of the global institution including the World Bank, IMF and G-8 Industrial Countries, when they shift the global economic policy for addressing the global poverty, inequality and unemployment. In 1990's, globalization, liberalization and privatization policy led Nepal for structural and policy change in trade (i.e. from import intensive trade policy to export intensive trade policy and state led economic system to private sector led liberal economic system) as well. This openness was an obligatory situation to Nepal in the context of higher dependency on the global institution and also the restoration of the open political system (called Multiparty Democratic System). However, literatures have established relationship between TPS towards trade liberalization, welfare and economic growth. With the development of endogenous growth theory (for example, Romer, 1990; Romer \& RiveraBatiz (1991); Grossman \& Help-man (1991) and Segerstrom, Anant \& Denopoulos (1990) a clear theoretical link has been provided from trade liberalization to economic growth. Similarly, international trade economists have typically argued that an open trade regime is very important for economic development. This view has been based partly on neoclassical trade theory, which generally finds that a country improves its welfare from trade liberalization, partly on casual empirical observation that countries which remain highly protected for long periods of time appear to suffer significantly and perhaps cumulatively, and partly on systematic empirical work that also finds trade liberalization beneficial to welfare/growth (Sachs \& Warner, 1995; Rutherford, 1998).

There are suspicious on TPS done by the democratic government whether it is right or wrong and it will be effective in trade development or not, despite successful empirical results. Therefore, there are found extreme and soft voices against globalization, liberalization and privatization policy at the policy level, the business community and the political level, although Nepal gives top priority on trade development for redistribution of income and welfare at household level as well as economic growth for poverty reduction and employment opportunities at national level.

\section{Research Objectives}

- To assess direction/effectiveness of India and Nepal trade development policies.

- To analyze the relationship between trade and the growth of real GDP of the country. 


\section{Research Design}

Comparative, descriptive and analytical methods are applied in this study. The data used in the study is quantitative and time series (from 1990 to 2014). They are collected from the secondary sources. They are Economic Survey, (Ministry of Finance), Trade Statistics, Trade Promotion Center (GoN) and FNCCI. Correlation and two variable simple logarithmic regression models* are applied. The model follows similar previous studies and methodologies followed by Pesmzoglu (1972), Modigliani (1970), Thirlwall (1974) and Poudyal (1974).

*Functional relationship between real GDP and Export to India

Real GDP (Y) is a function of Export to India $\left(\mathrm{X}_{\mathrm{in}}\right)$. Symbolically,

$\mathrm{RGDP}=\mathrm{f}\left(\mathrm{a}, \mathrm{X}_{\mathrm{in}, \mathrm{e}}\right)$

In the simple logarithmic regression model, it is

In $\mathrm{Y}_{\mathrm{i}}=$ In $\mathrm{a}+\mathrm{b}$ In $\mathrm{X}_{\text {ini }}+\mathrm{e}_{\mathrm{i}}$.

*Functional relationship between real GDP and Import from India ( $\left.\mathrm{Y}_{\text {in }}\right)$

Real GDP (Y) is a function of Import from India $\left(\mathrm{X}_{\mathrm{in}}\right)$.

$\mathrm{Y}=\mathrm{f}\left(\mathrm{a}, \mathrm{X}_{\text {in }}, \mathrm{e}\right)$

The functional relationship is set up in the simple regression model format for regression test on the empirical data used in the study.

In $_{\mathrm{i}}=$ Ina + bIn $\mathrm{X}_{\text {ini }}+\mathrm{e}_{\mathrm{i}}$

Where, $a=$ intercept, $b=$ coefficients of FDI, e=error term

\section{Major Empirical Results}

The contribution of TPS to real GDP in Nepalese economy is estimated by considering the export to India and the import from India as the explanatory variables. The dependent variable is Real GDP of Nepal. The result of the correlation and simple logarithmic regression model of Real GDP and Export to India and real GDP and Import from India are summarized in table 1 and 2.

Table 1. The Correlation Analysis of Real GDP, Export and Import Trade

\begin{tabular}{llc}
\hline Trade Policy & Correlation & Pearson's Coefficient (r2) \\
\hline Import Intensive Trade Policy & Real GDP and Export to India & $0.39^{*}$ \\
and State led & Real GDP and Import from & $0.604^{*}$ \\
& India & $0.937^{* *}$ \\
Export Intensive Trade Policy & Real GDP and Export to India & $0.932^{* *}$ \\
and Liberalization led & Real GDP and Import from & \\
& India & \\
\hline
\end{tabular}

*Correlation is significant at the 0.05 percent level (1-tailed)

**Correlation is significant at the 0.01 percent level (1-tailed)

Table 2. Regression Analysis of Real GDP, Export and Import Trade

\begin{tabular}{lllllllc}
\hline Dependent Variable & $\begin{array}{l}\text { Explanatory } \\
\text { Variable }\end{array}$ & Constant & $\mathbf{B}$ & $\begin{array}{l}\text { ADj } \\
\mathbf{R}^{\mathbf{2}}\end{array}$ & F-stat & t-stat & Std.error \\
\hline Real GDP in the Import & Export & -70762.6 & 105.008 & 0.031 & 1.255 & 1.120 & 57070.473 \\
Intensive Trade Policy & Import & -77252.2 & 36.972 & 0.274 & 4.020 & 2.005 & 49393.44 \\
$\begin{array}{l}\text { Period\& State led } \\
\text { Real GDP in Export }\end{array}$ & Export & 190512.5 & 3.563 & 0.868 & 93.267 & 9.657 & 15863.615 \\
Intensive Trade Policy \& & Import & 175336.5 & 1.775 & 0.859 & 86.6 & 9.306 & 16358.98 \\
Liberalization led & & & & & & & \\
\hline
\end{tabular}

This paper uses two different models including the correlation model and also simple logarithmic regression model. 


\section{The Correlation Model}

The estimated correlation coefficients in Import led trade policy before 1990 and Liberal Trade Policy after 1990 are positive in 0.01 percent and 0.05 percent level of significant implying that the real GDP growth and import and export growth are positively correlated. Before 1990, the trade policy was import intensive and protective character. The Pearson's correlation coefficient of real GDP and export to India is only 0.39 implying that there is only 39 percent correlation between real GDP and export to India, while the Pearson's correlation coefficient of real GDP and Import from India is 0.604 implying that there is 60 percent correlation between real GDP and Import from India. The correlation model explains that the trade policy would be unfavorable to develop the Indo-Nepal Trade. In addition, the export to India hadn't contributed more to real GDP than the import trade. Therefore, real GDP couldn't get acceleration.

After 1990, trade policy was shifted to export intensive and liberal trade policy. The Pearson's correlation coefficient of real GDP and export to India is 0.937 implying that there is 93.7 percent correlation between real GDP and export to India. The Pearson's coefficient of real GDP and import from India is 0.932 implying that there is 93.2 percent correlation between real GDP and import from India. The correlation model explains that the trade policy is favorable to the growth of Indo-Nepal Trade with the growth of export and import for real GDP growth.

The policy comparison on the basis of the Pearson's Correlation Coefficient explains better correlation coefficient in export and import in Indo-Nepal with real GDP in the Export Intensive Trade Policy than Import Intensive Trade policy. Therefore, the existing liberal and export intensive trade policy may be best in the aspect of real GDP growth for Indo-Nepal trade development; although there is different visible and invisible trade barriers.

\section{The Regression Model}

The model relating to the Import Intensive Trade Policy explains positive regression coefficient (Adj. $\mathrm{R}^{2}$ ) at 0.031 magnitudes that has very weak explanatory power of export trade having 3.1 percent explaining to the variation of real GDP because of larger unknown factor's presence. It may not give perfect goodness to fit. The model in the import trade of Indo-Nepal Trade explains positive coefficient (Adj. $\mathrm{R}^{2}$ ) at 0.274 that is also weak to explain higher variation of real GDP explains only 27.4 percent variation of real GDP because of larger unknown factor's presence.

The model in the export trade in the Export Intensive Trade Policy gives positive regression coefficient of 0.868 implying that the export trade in Indo-Nepal explains 86.8 percent variation of real GDP. Similarly, the model in the import trade in Indo-Nepal gives positive regression coefficient of 0.859 implying that the import trade explains 85.9 percent variation of real GDP. The model explains perfect goodness of fit and strong regression because there may be positive direction and effectiveness of the policy shift for reducing the existing unknown and known trade barrier in Indo-Nepal Trade. The comparative study on the basis of regression coefficient magnitude explains that the policy shift from the import intensive Trade Policy to the export intensive trade policy and also to liberalization is in right direction. Its effectiveness of the policy shift in trade development including export and import trade development may be higher than import Intensive Trade Policy. 


\section{Conclusion}

This paper estimates the contribution of export and import trade to real GDP in IndoNepal Trade in direction and effective Two Policy modules: the Import Intensive Trade Policy before 1990 and the Export Intensive Trade Policy after 1990. This is based on the secondary data of FDI, real GDP and Export trade. The correlation and simple logarithmic regression model is used for its estimation. The application of the model has resulted that the contribution of Export and Import Intensive Trade GDP in the Import Intensive Trade Policy before 1990 and the Export Intensive Trade Policy after 1990 positive with significant change value. The correlation coefficient and the regression coefficient explain positive and effectiveness of the Export Intensive Trade Policy for Trade development of Indo-Nepal Trade. Behind this, India has partially liberalized trade barrier to Nepal with preference. Therefore, Indo-Nepal Trade growth is found higher than before 1990. But it is not adequate to develop Indo-Nepal Trade. Therefore, the policy maker, the business community, the politician and the planner should initiate to reduce the unknown trade barrier in the Indian side through Nepal and India dialogue and trade negotiation for increasing the export trade of Nepal.

\section{References}

Cherunilam, F. (2007). International economics. New Delhi (India): McGraw-Hill Publishing Company Limited.

Coudouel, A., \& Stefano, P. (2005). Analyzing the distributional impact of reforms. Washington, DC: The World Bank.

Grossman, G., \& Helpman, E. (1991). Innovation and growth in the global economy. Cambridge: MIT Press, MA.

Harberler, G. (1959). The theory of international trade. London: William Hodge \& Co.

Panta, B. (2005). Nepal's trade sector: Review, repercussions and recommendations. Economic Review. Kathmandu: Nepal Rastra Bank (NRB).

Ricardo, D. (1817). Principles of political economy and taxation. Washington, DC: Cambridge University Press.

Romer, P. M. (1987). Growth-based on increasing returns due to specialization. American Economic Review, 77 (2), 56-62. New York: MIT Press.

Romer, P. M. (1990). Endogenous technological change. Journal of Political Economy, 98 (5), 71102.

Rutherford, T. F., \& Tarr, D. G. (1998). Trade liberalization and endogenous growth in a small open economy: A quantitative assessment. Washington, DC: International Monetary Fund (IMF).

Sachs, J. D., \& Warner, A. (1995). Economic reform and the process of global integration. In W. C. Brainard \& G. L. Perry (Eds.), Brookings Papers on Economic Activity (pp.1-117). Washington, DC: Oxford University Press.

Segerstrom, P. S, Anant, T. C. A., \& Dinopoulos. E. (1990). A schumpeterian model of the product life cycle. American Economic Review, 80 (3), 1077-1092.

Shakya, B. M. (1991). Foreign trade and export management in Nepal (pp. 90-103). Kathmandu: Ratna Pustak Bhandar.

Smith, A. (1776). The Wealth of Nations. London: Oxford University Press. 